MATEC Web of Conferences 47, 04020 (2016)

DOI: $10.1051 /$ matecconf/20164704020

(C) Owned by the authors, published by EDP Sciences, 2016

\title{
Properties of Agro-Industrial Aerated Concrete as Potential Thermal Insulation for Building
}

\author{
Eeydzah Aminudin ${ }^{1, a}$, Mohd Fadhil Md Din ${ }^{2}$, Mohd Warid Hussin ${ }^{3}$, Abd Halid Abdullah ${ }^{1}$, Kenzo Iwao ${ }^{4}$ \\ and Yo Ichikawa ${ }^{4}$ \\ ${ }^{1}$ Faculty of Civil and Environmental Engineering, Universiti Tun Hussein Onn Malaysia, 86400 Parit Raja, Johor, \\ Malaysia \\ ${ }^{2}$ Institute of Environmental Water Resources and Management, Universiti Teknologi Malaysia, 81310 Skudai, Johor, \\ Malaysia \\ ${ }^{3}$ Construction Research Centre, Faculty of Civil Engineering, Universiti Teknologi Malaysia, 81310 Skudai, Johor, \\ Malaysia \\ ${ }^{4}$ Nagoya Institutes of Technology, Gokiso, Showa, Nagoya, Aichi 466-8555, Japan
}

\begin{abstract}
The present paper is aiming to provide an actual state of the development of non autoclaved Agro-Industrial aerated concrete by using multiple ashes as improvement of thermal behavior for building. The feasibility of Agro-Industrial wastes as lightweight concrete by utilizing the Palm Oil Fuel Ash (POFA) as binder replacement and bottom ash as fine aggregate was investigated in this paper. Portland cement, bottom ash, aluminum powder and lime $(\mathrm{Ca}(\mathrm{OH}) 2)$ were used in this study. The POFA was used to replace Portland cement and Hydrated Lime at $0 \%, 5 \%, 10 \%$ and $15 \%$ by weight and aluminum powder was added at $0.75 \%$ dry weight in order to form bubbles. The compressive strength, water absorption, porosity and the thermal conductivity test were carried out after the concrete were water cured for 7 days and later being exposed to the air and water until 28days. The results show that the $20 \%$ replacements give the optimum strength of $7.143 \mathrm{MPa}$ and $30 \%$ give the best thermal conductivity with $0.48 \mathrm{~W} / \mathrm{mK}$. Hence, this study aim, was to develop an agro-industrial aerated concrete good in insulation but having an optimum strength. Hence, it has been found that the more the percentage of POFA is added the lower the thermal conductivity since the pore structure is increasing and by the optimization done, 30\% replacement has been chosen as the best mix design for Agro-Industrial Aerated Concrete.
\end{abstract}

\section{Introduction}

In the world of urbanization, lightweight concrete has become a perfect product as construction materials since it offers advantages such as light in densities ranging from 1000 to $1600 \mathrm{~kg} / \mathrm{m}^{3}$, having a great fire protection, good in thermal and sound insulations compared to normal weight concrete [1]. Normally aerated concrete consists of a mixture of sand, lime, cement, gypsum, water, and an expanding agent [15]. [17] classified there are three divisions on the basic of strength and unit weight: low density or low strength concrete $(0.7-2.0 \mathrm{MPa}, 300-800 \mathrm{~kg} / \mathrm{m} 3)$ used for insulation; moderatestrength lightweight concrete $(7-14 \mathrm{MPa}, 800-1360 \mathrm{~kg} / \mathrm{m} 3)$ used for concrete block together with other

\footnotetext{
${ }^{\mathrm{a}}$ Corresponding author : eeydzah@uthm.edu.my
} 
applications for strength and structure lightweight concrete (17-63MPa, 1300-1900kg/m $\mathrm{m}^{3}$ [ [2]. This study focusing on the moderate-strength lightweight concrete as it is main application for non-load bearing wall that comes with insulations properties. It is important to develop such materials for mitigation due to climate change or known as Urban Heat Island (UHI) issues.

Lightweight concrete or also known as thermal insulation is one of key factor for assessing the material composition of building envelops [21]. This is because the behavior of materials will determine the properties which are important for urban thermal balance. Besides that the long term benefit of insulation is that it may reduce the cost of cooling as well as reducing the pollution of the environment [3]. Heat from solar radiation will be absorbed and the infrared will radiate and dissipate part of the accumulated heat through convective, conduction and radiation. Some of heat will reradiate back to the atmosphere causing the increasing of ambient temperature. Thus, technical characteristics of materials used need to comply with determination degree of energy consumption and comfort conditions of individual buildings as well as of open spaces [4].

Aerated concrete known as lightweight concrete has been used in current construction materials. Such invention, lots of other extensive research progress aiming in improving the thermal, hygric and other structure properties. Majority, researched innovation conducted in Table 1 proved that either the replacement of cement or fine aggregate proven that the it might lower the density as well as thermal conductivity hence create a better insulation. As been cited by [5] the reduction of density of mortar means probably due to high air content. This has been agreed in Fu and Chung, 1997 cited in [5] study showed that low thermal conductivity is related to high air void. However, study showed by [2], proved that the thermal conductivity (Tc) differ, depends upon the pore structure of the lightweight aggregates, density of concrete and the cement paste matrix. Thus, the pore structure is one of the main factors affecting Tc.

Still the limitation shows that non load bearing structures rarely proves the percentage of wastage can improve thermal behavior including the value of Tcand the improvement in heat flux. Hence for this segment the researcher would like to discuss the behavior of adding and combining the wastes from Agricultural and Industry can improve the behavior of thermal conductivity, as improving the thermal comfort. Develop an efficient building materials is important as to minimize the consumption of electricity [8].

\section{Materials and Methods}

\subsection{Materials used for the experiment}

Materials used in this study consist of Ordinary Portland Cement, Calcium hydroxide $\left(\mathrm{Ca}(\mathrm{OH})_{2}\right)$, Bottom Ash from Power Plant as replacement of sand, POFA, aluminum powder, super plasticizer and water. Bottom ash was first pretreated by crushing and particle size classification method to decrease its higher unburned carbon to desirable level or that gen. The bottom ash was from Tanjung Bin Power Plant, Malaysia and has been oven dried at the temperature of $110^{\circ} \mathrm{C} \pm 5$ for 24 hour which later has been sieved before stored in airtight container. The Bottom Ash used in this study conforms with BS 882: 1983 and ASTM C 33-84, standard grading requirements for fine aggregate. The POFA used is a by-product obtained from burning the remaining of palm oil fibers and shells from Kahang Palm Oil Mill located in southern Malaysia. The collected ashes were dried in the oven at the temperature of $110^{\circ} \mathrm{C} \pm 5$ for 24 hour to remove all the moisture content before sieved and ground to obtain finer particles. Aluminum powder was used as a pore-foaming agent which reacts with calcium hydroxide to form hydrogen gas (gas bubbles) in cement slurry. The reaction in making aerated concrete was as follow [22] as shown in Equation (1).

$$
2 \mathrm{Al}(\mathrm{s})+3 \mathrm{Ca}(\mathrm{OH})_{2}(\mathrm{~s})+6 \mathrm{H} 2 \mathrm{O} \rightarrow 3 \mathrm{CaO} \cdot \mathrm{Al}_{2} \mathrm{O}_{3} \cdot 6 \mathrm{H}_{2} \mathrm{O}+3 \mathrm{H}_{2}(\text { gas })
$$

Besides that powder form super plasticizer classified as type superplasticizers sulfonated naphthalene in powder form confirming to ASTM C-494-05 (ASTM 2005a) type A and ASTM type B, D 
respectively were employed in all agro-industry aerated concrete. Superplasticizer was being introduced as admixtures as it may add fluidity to the concrete while less water is being used. In addition, it also plays a significant role to reduce the flocculation of cement grains [23]. In the case of aerated concrete production, insufficient presence of superplasticizer may fail the dispersion of cement particles thus producing a mix with a very low workability. Hence, created medium cause's disruption to the aeration process which is crucial for decreasing the density of aerated concrete. Besides that, the use of BA in fine aggregate will also create a higher expansion as compared to sand with the increment percentage of superplasticizer. This might due to the porous structure of bottom ash which requires a lot water content hence leads to the reduction of compressive strength [9].

Table 1. Previous study on the additional of pozzolonic material for thermal conductivity.

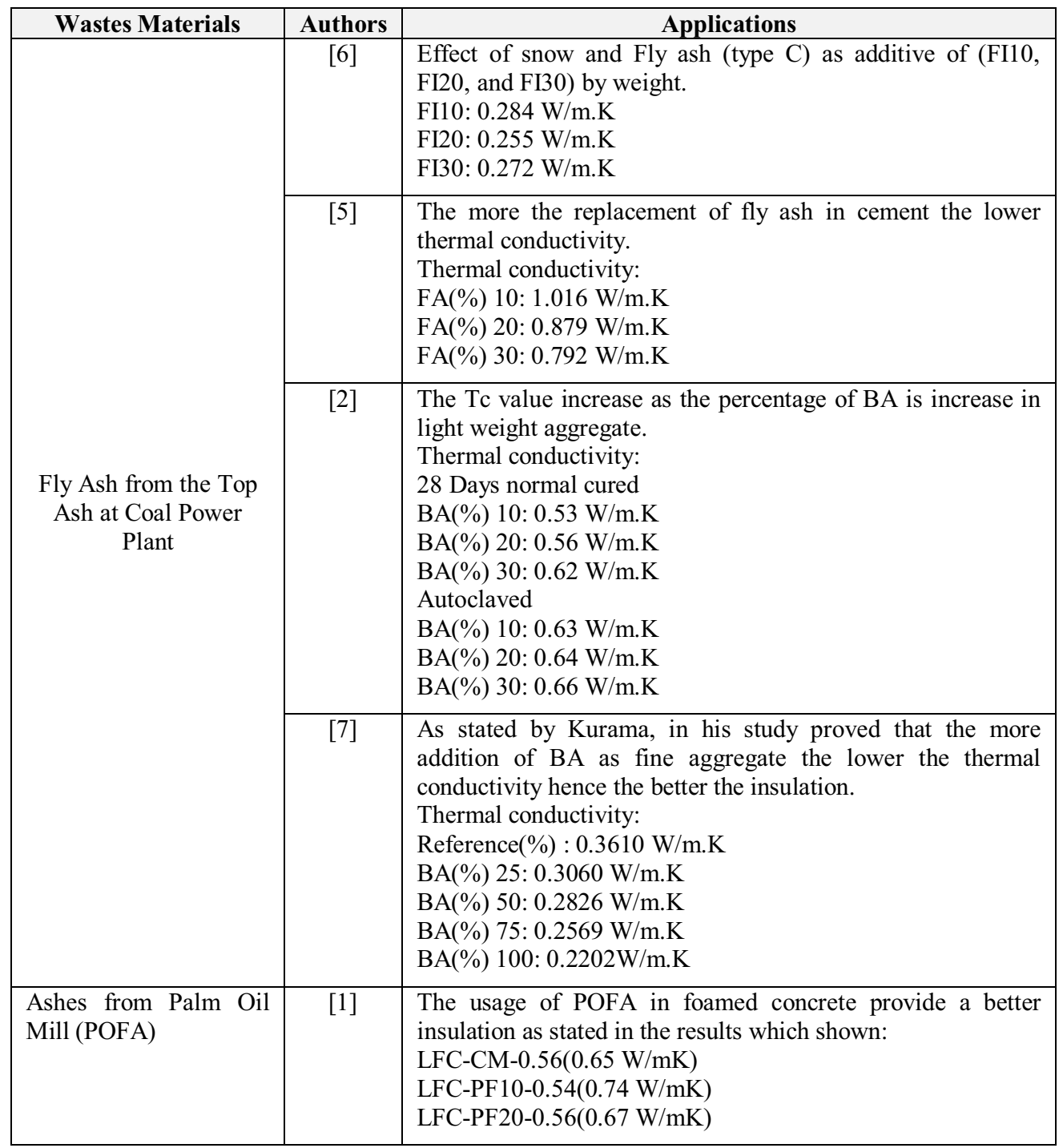

\subsection{Chemical composition of materials}

Based on data presented in Table 2, shows the percentage of chemical compositions of materials used in this research. The sum of $\mathrm{SiO}_{2}, \mathrm{Al}_{2} \mathrm{O}_{3}$ and $\mathrm{Fe}_{2} \mathrm{O}_{3}$ in POFA is $62.28 \%$ with $\mathrm{CaO} 5.70 \%$. It has shown 
that the type of fly ash is Class C Fly Ash with the min percentage of SO3 of $1.06 \%$. Based on the previous research that had done by [24] the quality of burning is depends on the burning process. The silica or silicon oxide $\left(\mathrm{SiO}_{2}\right)$ is perhaps the most essential substance which is found in POFA and contains most like more then $40 \%$ [18]. The amount of crystalline phase also can be found in POFA [10].

Table 2. Chemical composition of materials used in this research.

\begin{tabular}{|c|c|c|c|}
\hline Oxide & Portland Cement (\%) & POFA (\%) & Calcium Hydroxide (\%) \\
\hline $\mathrm{SiO}_{2}$ & 18.45 & 52.73 & 0.02 \\
\hline $\mathrm{Al}_{2} \mathrm{O}_{3}$ & 4.07 & 2.13 & 0.01 \\
\hline $\mathrm{CaO}$ & 60.85 & 5.70 & 31.39 \\
\hline $\mathrm{Fe}_{2} \mathrm{O}_{3}$ & 3.19 & 7.42 & 0.00 \\
\hline $\mathrm{MgO}$ & 2.85 & 3.94 & 0.55 \\
\hline $\mathrm{K}_{2} \mathrm{O}$ & 0.22 & 6.87 & 0.1 \\
\hline $\mathrm{P}_{2} \mathrm{O}_{5}$ & 0.06 & 3.18 & 0.00 \\
\hline $\mathrm{TiO}_{2}$ & 0.12 & 0.17 & 0.17 \\
\hline $\mathrm{MnO}^{\mathrm{SO}} \mathrm{O}_{3}$ & 0.12 & 0.33 & 0.18 \\
\hline & 4.04 & 1.06 & 13.04 \\
\hline
\end{tabular}

\subsection{Preparation of mix proportions}

In this research, cement/calcium hydroxide (lime)/sand ratio (C: $\mathrm{CH}: \mathrm{S}$ ratio) were used based on Ing, E, 2010 in [25]. The novelty for this study was bottom ash has been used 100\% replacing the sand. The $100 \%$ bottom ash as the fine aggregate is been set as the control specimen. The specimen has been mixed with three different stages which the first stage was the mixing preparation of cement, hydrated lime, POFA, and Bottom Ash. Next, the additives were added with aluminum powder and super plasticizer. The water dry mix ratio has been varies with different percentage of POFA $(0,10$, $20,30,50 \%)$ in order to determine best mix ratio. Table 3 represents the mix proportion of ArgoIndustrial Aerated Concrete. At the end of the stage the water is added before cast in the form of cubes $(70 \times 70 \times 70 \mathrm{~mm})$. All specimens were left in the mold for $24 \mathrm{~h}$ before being demolded and subjected to water curing for first 7 days continued with different curing regimes until the time is ready to test.

Table 3. Mix proportion of agro-industrial aerated concrete.

\begin{tabular}{|c|c|c|c|c|c|}
\hline \multirow{3}{*}{ Materials } & \multicolumn{5}{|c|}{ Mix design } \\
\hline & \multicolumn{5}{|c|}{$\mathrm{C}: \mathrm{CH}: \mathrm{BA}=25: 25: 50$} \\
\hline & $\mathrm{CS}$ & $0 \%$ & $10 \%$ & $20 \%$ & $30 \%$ \\
\hline Cement $\left(\mathrm{kg} / \mathrm{m}^{3}\right)$ & 214 & 214 & 203.3 & 192.6 & 183.5 \\
\hline Hydrated Lime $\left(\mathrm{kg} / \mathrm{m}^{3}\right)$ & 214 & 214 & 203.3 & 192.6 & 183.5 \\
\hline POFA $\left(\mathrm{kg} / \mathrm{m}^{3}\right)$ & - & - & 21.4 & 42.8 & 61 \\
\hline Sand $\left(\mathrm{kg} / \mathrm{m}^{3}\right)$ & 428 & - & - & - & - \\
\hline Bottom Ash $\left(\mathrm{kg} / \mathrm{m}^{3}\right)$ & - & 428 & 428 & 428 & 428 \\
\hline
\end{tabular}

All specimens were tested to determine density and compressive strength at the age of 7 and 28 days. Compressive strength test was conducted in accordance to BS 1881:116 (British Standard Institution 1983). The aerated concrete which having the lower dense with an adequate strength and lower in thermal conductivity suitable for non load bearing application as stated in ASTM C129-85 (ASTM 1990) was chosen as the optimum design mix for control. In this research focused on the non autoclaved aerated concrete due to the awareness on reducing the effect on global warming even though as been stated by Tada in [26] claim that non autoclaved will produced a lot of macro-size distribution which will not influence the strength. At the end of the experiment, the thermal conductivity test has been identified, using BS EN 12664:2001 standard. 


\section{Results and Discussion}

\subsection{Influence of water dry mix ratio in agro-industrial aerated concrete}

Maintaining correct water content of the aerated concrete mix is important to control the early stages of the manufacturing process. If the water / dry mix ratio is too low the mix will be very viscous at casting and will make the expansion become impeded and the mix will not reach the correct final height. Vise verse, if the water/dry mix content is too high the cast for the aerated concrete will become low in viscosity and the stability will may be reduced. As reported on the action of compressive strength value and density with respect to water dry mix ratio in Figure 1 different percentage of POFA give different results on the strength. Based on Figure 1, it is reported that water dry mix ratio of $0.2 \%$ give the best strength for all mixes. This might due to the effect of POFA which has a pozzolanic properties besides having portlandite, that may enhance the strength of concrete at 28 Days [27]. Basically at optimum percentage of $20 \%$ replacement of POFA will give a higher strength [14]. As water depleting, the lower the creation of macropores entrapped within the hardened mix making the specimen not only heavier but possess high strength and a denser weight recorded. Still, insufficient water will create lots of internal stress (internal capillary) between the matrix and it might have the capability to be burst off and create a larger crack mode on the surface. The internal stress is much related to the capacity of cement paste produced.

Hence, adequate water is important due to the formation of cellular internal structure. The cellular structure is very important as it will depend on the level of expansion which offers explanation for the gradual drop of density and strength when water increased. In general, the level of water dry mix ratio can be selected depending on the targeted density and strength of aerated concrete.

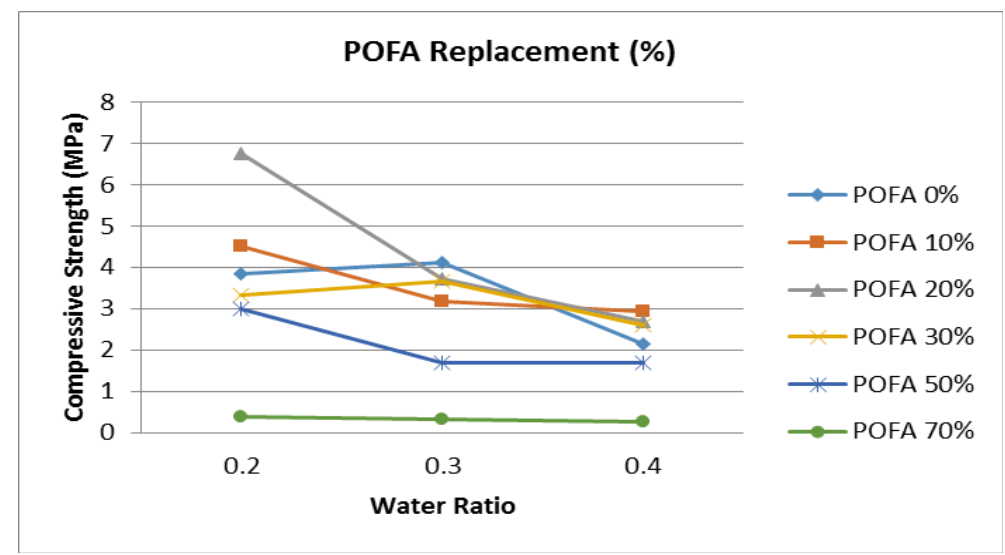

Figure 1. Variation of compressive strength with water dry mix ratio for mixes containing different amounts of POFA.

\subsection{Relationship between mechanical properties of POFA in aerated concrete}

Majority, researched innovation conducted in Table 1 proved that either the replacement of cement or fine aggregate proven that the higher the replacement when the lower the density, the lower the thermal conductivity hence a better insulation created. As been cited by [5] the reduction of density of mortar means probably due to high air content. This has been agreed in Fu and Chung, cited in [5] study showed that low thermal conductivity is related to high air void. However, study showed by [2] proved that the thermal conductivity differ, depends upon the pore structure of the lightweight aggregates, density of concrete and the cement paste matrix. Thus, the pore structure is one of the main factors affecting thermal conductivity. 
Figure 2 indicates the mechanical properties including compressive strength, density, thermal conductivity and also the porosity value which narrow even precisely the indication for the best selection of mix based on the characteristic on reducing the thermal comfort. Overall, the higher percentage of POFA means that the more total of fines in matrix structure of aerated concrete. [28] findings shows that higher amount of fly ash leads towards lower density in aerated concrete. $20 \%$ replacement of POFA showed the highest strength among others at 28 days with $7 \mathrm{MPa}$. This might due to the pozzolanicity of POFA which plays the role in densifying internal structure through formation of C-S-H gel that fills the existing pores. This finding has been agreed by [29] which found that replacement of POFA up to $30 \%$ give the highest strength among the others. Pozzolanic reaction is a secondary reaction which forms the Calcium Hydroxide crystal from hydrating cement grains. Too much of POFA will not generate a higher strength development since lower content of calcium hydroxide produced from hydration process.

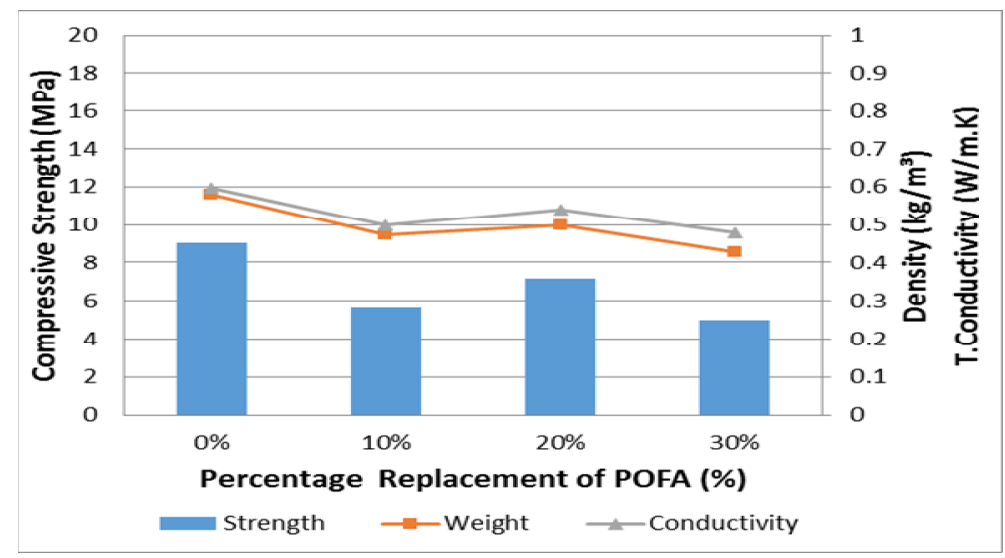

Figure 2. Overall properties for mixes containing different amounts of POFA subjected to different curing regimes at the age of 28 days.

But since, the knowledge of this study is more concerning on the behavior of thermal in the concrete hence, the thermal insulation has became the prior of the art of knowledge. The infrared thermograph was used as the technique to detect the behavior of the thermal load for particular brick at different time duration. By comparing three replacement percentages POFA for thermal insulation, it was found that 30 per cent gave better insulation properties yet with an adequate strength. The thermal conductivity from 30 per cent was $0.48 \mathrm{~W} / \mathrm{m} . \mathrm{K}$ lesser even compared to the control aerated concrete with $0.5965 \mathrm{~W} / \mathrm{m} . \mathrm{K}$. Hence, the values of thermal conductivity decrease with the increasing percentage of POFA replacement. Again, it has been agreed in Fu and Chung, 1997 cited in [5] study showed that low thermal conductivity is related to high air void. Study showed by [6] stated that 20 per cent replacement gave the lowest value of thermal conductivity compared to control,10 and 30 per cent. The optimum proved that the samples have a highest amount of isolated voids compared to others. The basic idea behind using aerated concrete was to attain elongation of the heat flow path through the wall. The direct heat flow through vertical transverse joints was avoided by cancelling vertical joints fully filled with [3]. This caused to a high value of thermal conductivity.

\subsection{Selected design mix}

Based on the results obtained from the trial and error method, the mix having a lower density and exhibit an adequate strength for non load bearing wall with lower in thermal conductivity value has been chosen. It has been discovered that the replacement of $20 \%$ POFA exhibit the greatest strength at later age. As for 30\% POFA it gave a bit lower strength but having an adequate strength with low thermal conductivity. As been stated in previous discussion, lower density, will create a more pores 
created between matrixes hence resulting a lower thermal conductivity value. Hence, in this study the aim investigates the lowest thermal conductivity in order to produce a high in time lagged which later will reduce the heat to transfer into a building. Table 4 shows the best mix design selected based on exhibit an adequate strength for non-load bearing specified in ASTM C129-85 (1990). As a control, 3 different mixes has been studied. First, the control having sand replacement in aerated concrete, control mortar based on $\mathrm{C} 117$ and commercial brick.

Table 4. Mix proportion of Agro-Industrial aerated concrete.

\begin{tabular}{ll}
\hline Cement: Lime: Bottom Ash & $1: 1: 2$ \\
\hline Ordinary Portland cement (\%) & 70 \\
\hline POFA Replacement (\%) & 30 \\
\hline Sand Fineness & Passing 4.75mm \\
\hline Water Dry Mix Ratio & 0.29 \\
\hline Alum Powder (\% of dry mix) & 1.5 \\
\hline Superplasticizer (\%) & 1 \\
\hline
\end{tabular}

\subsection{Microstructure}

In aerated concrete, pore system normally divided into 3 regions. Based on [30] air pores with a radius of 50 to $500 \mu \mathrm{m}$ was introduced by hydrogen gas during manufacturing process and as for microcapillaries of $50 \mathrm{~nm}$ or less created between the gap of hydration developed in the wall between the air pores. It is also observed that the strength performance also influenced by this characteristic. It has been revealed that the porosity is not the unique parameter affecting the strength of concrete and many other factors such as pore size distribution, micro cracks, interface and other are also important factors for its properties. However, porosity which can semi-empirically describe the relationship between strength and microstructure for porous materials was still studied in this research. For the study of structure-property correspondence of aerated concrete, specimen having different porosity has been compared in Figure 3. From the results obtain, the regression line, $\mathrm{R} 2=0.8$. This indicates that the correlation in between compressive strength and porosity is strong. Compressive strength is very important in order to catter a suitable load for a particular mixing.

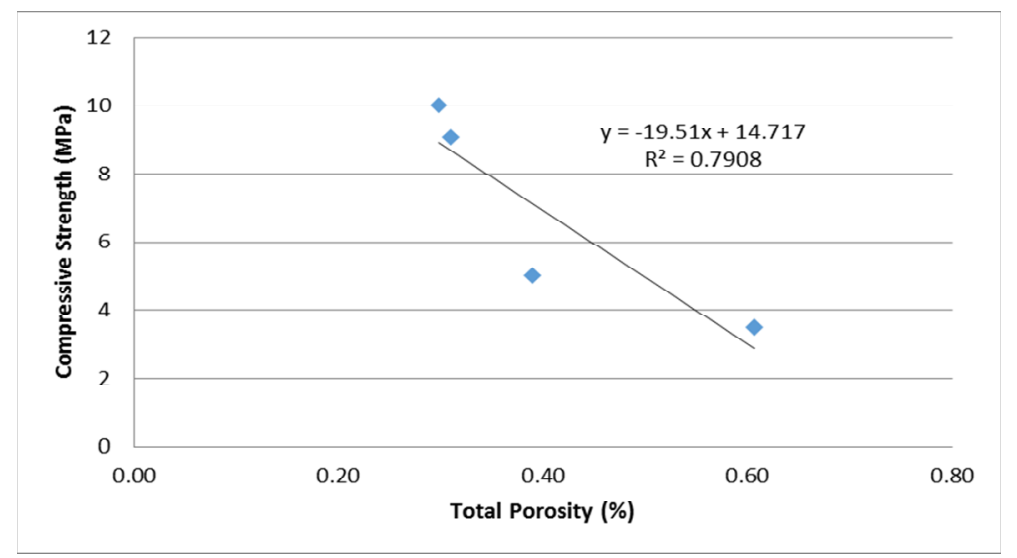

Figure 3. Relationship between total porosity and compressive strength of AC.

Besides that, variation of strength and density alter to different characteristic of air void or particle size distribution. It shows that the compressive strength increases with the decreasing of total porosity. According to [28] fine pore structure and narrow air void size caused increase in strength. A narrow 
air void will have well-structured cell in matrix form. The matrix link produces strengthen composition between one another. Figure 4 shows the pore size distribution diagarms and the mean diameters of bubbles for 30percent replacement. This can be understood as the fact that the increase of POFA will increase the total porosity and lower the bulk density. In other words, the larger volume of fine pore, thicker pore wall will have a uniform pore distribution from finest pore to macro capillary resulted from excessive process water. This can be proved by 30POFA having a pore diameter of 0.45 $\mu \mathrm{m}$ and density of $1225 \mathrm{~kg} / \mathrm{m}^{3}$ with the porosity of $39 \%$.

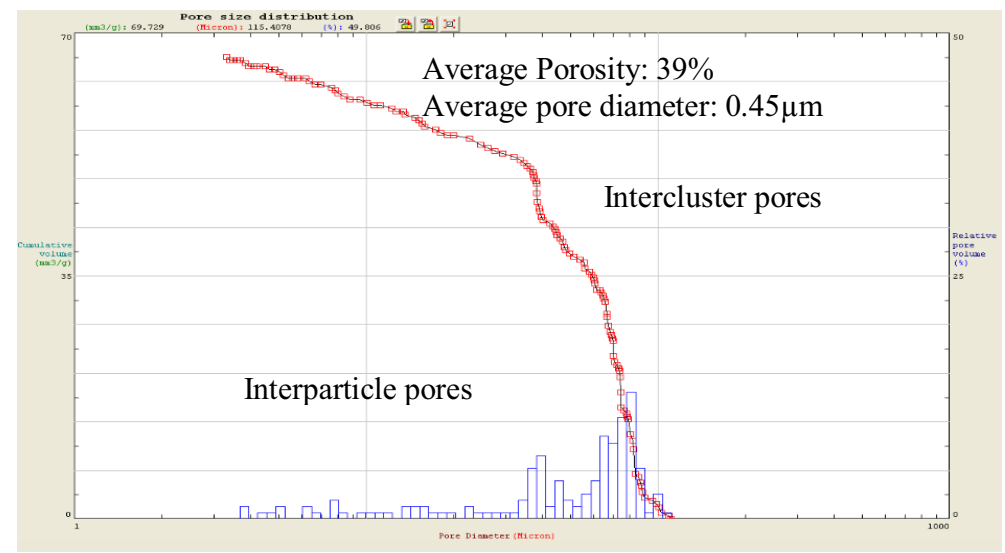

Figure 4. Pore size distribution diagrams and the mean diameters of bubbles for 30POFA.

\section{Conclusion}

On the basic of the results, the conclusion can be drawn: (i) POFA physical characteristic may exhibit the strength development for aerated concrete. The results show that the $20 \%$ replacements give the optimum strength of $7.143 \mathrm{MPa}$ and $30 \%$ give the best thermal conductivity with $0.48 \mathrm{~W} / \mathrm{mK}$, (ii) The $100 \%$ replacement of bottom ash $(0.52 \mathrm{~W} / \mathrm{m} . \mathrm{K})$ as the sand replacement may enhance the thermal conductivity value compared to the control aerated concrete by sand $(0.68 \mathrm{~W} / \mathrm{m} . \mathrm{K})$, (iii) The optimum mix design which give an adequate result in strength but improve the thermal properties which can act as insulation and can be utilize for materials especially non-load bearing wall as one of indicator to overcome the Urban heat island issues. It shows that 30\% POFA gave a better thermal comfort at night because it does not released back the heat at night, and (iv) The Agro-Industrial aerated concrete will produces initial needle-shaped hydrates which will change the structure into hexagonal and continues in block-shaped calcite crystals after the several years. Meaning to said, it will give a constant structure within years.

\section{References}

[1] S.K. Lim, C.S. Tan, O.Y. Lim and Y.L. Lee, Fresh and hardened properties of lightweight foamed concrete with palm oil fuel ash as filler, Constr.Build. Mater., 46, 39-47, (2013).

[2] W. Wongkeo and A. Chaipanich, Compressive strength, microstructure and thermal analysis of autoclaved and air cured structural lightweight concrete made with coal bottom ash and silica fume, Mater. Sci. Eng. A, 527(16-17), 3676-3684, (2010).

[3] K.S. Al-Jabri, A.W. Hago, A.S. Al-Nuaimi and A.H. Al-Saidy, Concrete blocks for thermal insulation in hot climate, Cem. Concr. Res., 35(8), 1472-1479, (2005).

[4] M. Santamouris, A. Synnefa and T. Karlessi, Using advanced cool materials in the urban built environment to mitigate heat islands and improve thermal comfort conditions, Sol. Energy, 85(12), 3085-3102, (2011). 
[5] R. Demirbog, Influence of mineral admixtures on thermal conductivity and compressive strength of mortar, 35, 189-192, (2003).

[6] A. Saygili and G. Baykal, A new method for improving the thermal insulation properties of fly ash, 43, 3236-3242, (2011).

[7] H. Kurama, İ.B. Topçu and C. Karakurt, Properties of the autoclaved aerated concrete produced from coal bottom ash, J. Mater. Process. Technol., 209(2), 767-773, (2009).

[8] L.M. Al-Hadhrami and A. Ahmad, Assessment of thermal performance of different types of masonry bricks used in Saudi Arabia, Appl. Therm. Eng., 29(5-6), 1123-1130, (2009).

[9] M. Singh and R. Siddique, Effect of coal bottom ash as partial replacement of sand on properties of concrete, Resour. Conserv. Recycl., 72, 20-32, (2013).

[10]C. Chandara, K.A.M. Azizli, Z.A. Ahmad, S.F.S. Hashim and E. Sakai, Analysis of mineralogical component of palm oil fuel ash with or without unburned carbon, Adv. Mater. Res., 173, 7-11, (2010).

[11]F.H. Wittman, Autoclaved aerated concrete, moisture and Properties. Developments in civil Engineering, Elsevier, (1983).

[12]M.W. Hussin, K. Muthusamy and F. Zakaria, Effect of mixing constituent toward engineering properties of POFA cement- based aerated concrete, J. of Materials in Civil Eng., 22(4), (2010).

[13] V. Sata,C. Jaturapitakkul and K. Kiattikomol, Utilization of palm oil fuel ash in high - strength concrete, Journal of Materials in Civil Engineering, 16, 623-628, (2004).

[14]K. Muthusamy, Properties of Palm Oil Palm Boiler Ash Fuel Ash Cement Based Aerated Concrete, PhD Thesis, Universiti Teknologi Malaysia, (2009),

[15]C. Karakurt, H. Kurama and I.B. Topçu, Utilization of natural zeolite in aerated concrete production, Journal of Cement and Concrete Composite, 32, 1-8, (2010).

[16]I. Kula, A. Olgun, V. Sevinc and Y. Erdogan, An investigation on the use of tincal ore waste, fly ash, and coal bottom ash as Portland cement replacement materials, Cem. Concr. Res., 32, 227232, (2002).

[17]ACI Committee 213, Guide for structural Lightweight Aggregate Concrete, (2001).

[18]N.F. Zainudin, K.T. Lee, A.H. Kamaruddin, S. Bhatia and A.R. Mohamed, Study of adsorbent prepared from oil palm ash (OPA) for flue gas desulfurization, Journal of Separation and Purification Technology, 45(1), 50-60, (2005).

[19]U.J. Alengaram, B.A. Muhit and M.Z. Jumaat, Utilization of oil palm kernel shell as lightweight aggregate in concrete - a review, Construction and Building Materials, 38, 161-172, (2013).

[20]W.T.L. Chow and M. Roth, Temporal dynamics of the urban heat island of Singapore, Int. J. Clim., 26, 2243-2260, (2006).

[21] V. Koc `í, J. Made ra, R. C`erny' and P. Rovnaníková, Application of a combined ComputationalExperimental Approach for Service Life Estimate of Exterior Plasters of Historical Buildings, WIT Press, Southampton, (2009).

[22] Short and Kinniburgh, Lightweight Concrete, CR Books, (1963).

[23]A.S.M.A. Awal and M.W. Hussin, Some aspects of durability performances of concrete incorporating palm oil fuel ash, Proc. of the 5th Int. Conf. on Structural Failure, Durability and Retrofitting, Singapore, (1997).

[24]N.K. Bansal, S.N. Garg and S. Kothari, Effect of exterior surface colour on the thermal performance of buildings, Building and Environment, 27(1), 31-37, (1992).

[25]I.A. Shehu and A.S.M. Awal, Mechanical properties of concrete incorporating high volume palm oil fuel ash, Advances Materials Research, 599, 537-540, (2012).

[26]K. Ramamurthy, E.K.K. Nambiar and G.I.S. Ranjani, A classification of studies on properties of foam concrete, Cement and Concrete Composite, 31, 388-396, (2009).

[27]A.S.M.A Awal, A Study of Strength and Durability Performances of Concrete Containing Palm Oil Fuel Ash, PhD Thesis,Universiti Teknologi Malaysia, (1998).

[28]N. Arreshvhina, Application of Slag Cement Based Aerated Lightweight Concrete In Non-Load Bearing Wall Panels, Master Thesis, Universiti Teknologi Malaysia, (2002). 